\title{
Fungicide application increased copper-bioavailability and impaired nitrogen fixation through reduced root nodule formation on alfalfa
}

\author{
Martin Schneider (10) ${ }^{1,2,3,6} \cdot$ Katharina M. Keiblinger ${ }^{1} \cdot$ Melanie Paumann $^{1} \cdot$ Gerhard Soja $^{2} \cdot$ Axel Mentler $^{1}$. \\ Alireza Golestani-Fard ${ }^{1,3}$ - Anika Retzmann ${ }^{4}$. Thomas Prohaska ${ }^{5}$ - Sophie Zechmeister-Boltenstern ${ }^{1}$. \\ Walter Wenzel $^{1} \cdot$ Franz Zehetner $^{1}$
}

Accepted: 22 April 2019 / Published online: 28 May 2019

(c) The Author(s) 2019

\begin{abstract}
Copper-based fungicides have been used for a long time in viticulture and have accumulated in many vineyard soils. In this study, incrementing $\mathrm{Cu}(\mathrm{OH})_{2}$-based fungicide application from 0.05 to $5 \mathrm{~g} \mathrm{Cu} \mathrm{kg}^{-1}$ on two agricultural soils (an acidic sandy loam (L, pH 4.95) and an alkaline silt loam (D, pH 7.45)) resulted in 5 times more mobile $\mathrm{Cu}$ in the acidic soil. The most sensitive parameters of alfalfa (Medicago sativa) growing in these soils were the root nodule number, decreasing to $34 \%$ and $15 \%$ of the control at $0.1 \mathrm{~g} \mathrm{Cu} \mathrm{kg}^{-1}$ in soil $\mathrm{L}$ and at $1.5 \mathrm{~g} \mathrm{Cu} \mathrm{kg}^{-1}$ in soil $\mathrm{D}$, respectively, as well as the nodule biomass, decreasing to $25 \%$ and $27 \%$ at $0.5 \mathrm{~g} \mathrm{Cu} \mathrm{kg}^{-1}$ in soil $\mathrm{L}$ and at $1.5 \mathrm{~g} \mathrm{Cu} \mathrm{kg}^{-1}$ in soil $\mathrm{D}$, respectively. However, the enzymatic $\mathrm{N}_{2}$-fixation was not directly affected by $\mathrm{Cu}$ in spite of the presence of $\mathrm{Cu}$ in the meristem and the zone of effective $\mathrm{N}_{2}$ fixation, as illustrated by chemical imaging. The strongly different responses observed in the two tested soils reflect the higher buffering capacity of the alkaline silt loam and showed that $\mathrm{Cu}$ mitigation and remediation strategies should especially target vineyards with acidic, sandy soils.
\end{abstract}

Keywords Endosymbiosis $\cdot$ Heavy metal $\cdot$ LA-ICP-MS $\cdot$ Pollutant $\cdot$ Toxicology $\cdot$ Trace element

Supplementary information The online version of this article (https:// doi.org/10.1007/s10646-019-02047-9) contains supplementary material, which is available to authorized users.

Martin Schneider

martin.schneider@boku.ac.at

1 Institute of Soil Research, University of Natural Resources and Life Sciences, Peter-Jordan-Straße 82, 1190 Vienna, Austria

2 Austrian Institute of Technology, Center for Energy, Konrad Lorenz-Straße 24, 3430 Tulln an der Donau, Austria

3 Division of Agronomy, University of Natural Resources and Life Sciences, Konrad Lorenz-Straße 24, 3430 Tulln an der Donau, Austria

4 Division of Analytical Chemistry, University of Natural Resources and Life Sciences, Konrad Lorenz-Straße 24, 3430 Tulln an der Donau, Austria

5 Chair of General and Analytical Chemistry, Montanuniversität Leoben, Franz-Josef-Straße 18, 8700 Leoben, Austria

6 Present address: Institut für Bodenforschung, Schwackhöfer Haus, Peter-Jordan-Straße 82, 1190 Wien, Austria

\section{Introduction}

Salts of $\mathrm{Cu}$ are used in agriculture since more than 120 years. Either $\mathrm{CuSO}_{4}$ or more recently also $\mathrm{Cu}(\mathrm{OH})_{2}$ show superior fungicidal properties and a lack of resistances of fungi, compared to synthetic fungicides (Kühne et al. 2009). Their preventive applications mitigate losses in photosynthetically active leaf area in vineyards, mainly caused by the infection with downy mildew (Plasmopara viticola). Current maximum application rates of $3 \mathrm{~kg} \mathrm{Cu} \mathrm{ha}^{-1}$ on conventionally grown grapevine in Austria, or $6 \mathrm{~kg} \mathrm{Cu} \mathrm{ha}^{-1}$ according to EU-legislation (EC 2008) are not supposed to cause remarkable increases in soil $\mathrm{Cu}$ contents, compared to inputs through sewage sludge or manure. The majority of contaminations on agricultural soil was caused by application rates of 30 and even up to $80 \mathrm{~kg} \mathrm{Cu} \mathrm{ha}^{-1}$ before 1970 (Kühne et al. 2009). Nevertheless, soils may show $\mathrm{Cu}$ accumulation due to low harvest withdrawals of $3-30 \mathrm{mg} \mathrm{kg}^{-1}$ plant dry weight (dw) (Amelung et al. 2018) and because of longterm use of $\mathrm{Cu}$-based fungicides, which is nowadays, especially in organic farming systems, still inevitable.

Especially former vineyards report total soil $\mathrm{Cu}$ concentrations of about $1030 \mathrm{mg} \mathrm{kg}^{-1}$ in France (Bravin et al. 2010; 
Michaud et al. 2007), $888 \mathrm{mg} \mathrm{kg}^{-1}$ in Austria (Berger et al. 2012), $493 \mathrm{mg} \mathrm{kg}^{-1}$ in Brazil (Girotto et al. 2014), $249 \mathrm{mg}$ $\mathrm{kg}^{-1}$ in Australia (Pietrzak and McPhail 2004) and $200 \mathrm{mg}$ $\mathrm{kg}^{-1}$ in Serbia (Ninkov et al. 2014). However, the probable no-effect levels calculated for soils range only from 55 to $155 \mathrm{mg}$ total $\mathrm{Cu} \mathrm{kg}^{-1}$ in Austria (Berger et al. 2012), whereas the German precautionary values only range from 20 to $60 \mathrm{mg}$ total $\mathrm{Cu} \mathrm{kg}^{-1}$ in sand or clay, respectively (BBodSchV 1999).

Besides the soil organic matter (SOM) content, representing the major sorption pool for $\mathrm{Cu}$, the sorption of $\mathrm{Cu}$ is governed by soil $\mathrm{pH}$, with stronger adsorption at $\mathrm{pH}>4.5$ (Lair et al. 2007; Lair et al. 2006) and higher mobility at pH $<4.5$ (Amelung et al. 2018; Cornu et al. 2007). Therefore, the main proportions of $\mathrm{Cu}$ are retained in the uppermost soil layer in association with SOM and thus do not cause detrimental effects on deep rooting perennial crops. However, $\mathrm{Cu}$ toxicity can be observed for annual intercrops, or when replacing the perennial crops by annual ones (Michaud et al. 2007).

$\mathrm{Cu}$ is a redox-active essential core element in various enzymes and cofactors. It is necessary for the electron transfer in photosynthesis as well as for the final reduction of $\mathrm{O}_{2}$ in the respiration chain via cytochrome-cbb ${ }_{3}$-oxidase (Brennicke and Schopfer 2010; White 2012). Toxicity mainly occurs by proliferation of cell membranes and the subsequent catalytic production of reactive oxygen species (ROS) via the Fenton- /Haber-Weiss-reaction (Díaz et al. 2001; Halliwell and Gutteridge 1984; Mostofa and Fujita 2013).

Due to restrictions in the use of synthetic fungicides and mineral fertilizers, organic viticulture depends on $\mathrm{Cu}$ as well as on co-cropping with legumes. Since Fabaceae are $\mathrm{Cu}-$ sensitive (Dahlin et al. 1997), there is a trade-off between effective plant protection and efficient $\mathrm{N}_{2}$-fixation.

Medicago sativa (lucerne or alfalfa) is a perennial plant and $\mathrm{N}_{2}$-fixing via endosymbiotic rhizobia, which support growth, nutrient uptake and resilience (Ashrafi et al. 2014). Rhizobium meliloti colonize fine roots and form root nodules. Every known rhizobium utilizes enzymes for the reduction of $\mathrm{N}_{2}$ into ammonia, i.e. mainly the $\mathrm{Mo} / \mathrm{Fe}-$ nitrogenase. Some strains are also capable to use $\mathrm{V}$ or only $\mathrm{Fe}$ as cofactors, if the availability of Mo is insufficient (Bellenger et al. 2014; Brennicke and Schopfer 2010; White 2012). To prevent the nitrogenases from inactivation trough free $\mathrm{O}_{2}$, the root nodules of legumes contain leghemoglobin to maintain microaerob conditions (Bellenger et al. 2014; Brennicke and Schopfer 2010).

It is known that $\mathrm{Cu}$ elevates $\mathrm{N}_{2}$-fixation up to $10 \mathrm{mg} \mathrm{Cu}$ $\mathrm{kg}^{-1}$ soil dw (Snowball et al. 1980). However, Baijukya and Semu (1998) showed decreasing biomass of Phaseolus vulgaris and plant-related number and biomass of nodules at application rates of $2.2 \mathrm{mg} \mathrm{Cu} \mathrm{kg}^{-1}$ soil dw. The potential
$\mathrm{N}_{2}$-fixation of alfalfa in perlite with nutrient solution at $\mathrm{pH} 6$ was reduced by $97 \%$ at $10 \mathrm{mg} \mathrm{Cu} \mathrm{L}^{-1}$ as $\mathrm{CuSO}_{4}$, with visual symptoms of plant toxicity at $100 \mathrm{mg} \mathrm{L}^{-1}$ (Porter and Sheridan 1981). Ippolito et al. (2011) observed no alfalfa growth at $500 \mathrm{mg} \mathrm{Cu} \mathrm{kg}^{-1}\left(\mathrm{CuSO}_{4}\right)$ applied after 5 weeks of growth. In a $\mathrm{CuSO}_{4}$-ammended natural forest soil with $\mathrm{pH}$ 5.9, Caetano et al. (2016) obtained effective concentrations with $50 \%$ decrease in harvest at 93 to $291 \mathrm{mg} \mathrm{Cu} \mathrm{kg}^{-1}$ soil $\mathrm{dw}$ for Lactuca sativa and for Avena sativa, respectively. The assumption of root proliferation (Voigt et al. 2006) being the main mechanism of Cu-toxicity is validated by (Chen et al. 2013) with $\mathrm{Cu}$-concentrations presenting the first significant increase in the same $\mathrm{CuSO}_{4}$-treatments as the decreases in root elongation.

In spite of numerous studies about $\mathrm{Cu}$ affecting plant growth, data about effects of $\mathrm{Cu}(\mathrm{OH})_{2}$ on $\mathrm{N}_{2}$-fixation is still scarce. Therefore, the objective of this study was to identify thresholds for significant impacts of $\mathrm{Cu}(\mathrm{OH})_{2}$-application on different plant compartments and $\mathrm{N}_{2}$-fixation of alfalfa, a typical cover crop in vineyards. This was tested after application on a wide range of soil $\mathrm{Cu}$ concentrations in two soils with contrasting properties. We hypothesized that the bioavailability of added copper is higher in the acidic soil, therefore resulting in lower toxicity thresholds compared to the calcareous soil. In particular, it was further hypothesized, that increasing $\mathrm{Cu}$ levels beyond the thresholds result in (a) decreased biomass production of different plant compartments (shoot, root, nodule), (b) elevated plant tissue $\mathrm{Cu}$ concentrations and (c) depressed nitrogenase activity.

\section{Materials and methods}

\section{Soil properties and experimental design}

We used an acidic sandy loam from Lasberg (L), Upper Austria, with a pH of $4.95\left(1: 12.5\right.$, w/v, soil/0.01 $\left.\mathrm{M} \mathrm{CaCl}_{2}\right)$ as well as an alkaline silt loam from Deutsch Jahrndorf (D), Burgenland, with a pH of 7.45 (Table 1).

Topsoils were sampled in March 2015 and sieved to $\leq 1 \mathrm{~cm}$. The unfertilized soils were filled into $4.8 \mathrm{~L}$ polypropylene (PP) pots $(\varnothing 20 \mathrm{~cm})$ at a bulk density of $1.2 \mathrm{~g} \mathrm{~cm}^{-3}$. The pots were equipped with a polyethylene fleece at the bottom, to prevent particle movement while flushing, and with $6 \mathrm{~mm}$ glass fiber wicks for passive watering. The wicks reached up to $50 \%$ of the pots height and down to the bottom of a black $5 \mathrm{~L}$ PP bucket, installed beneath the pots (Supp. Fig. 1). The buckets were filled with artificial rain water, i.e. desalinated water with $3 \mathrm{mg} \mathrm{Ca} \mathrm{L}^{-1}\left(50 \% \mathrm{CaCl}_{2}\right.$ and $\left.50 \% \mathrm{CaSO}_{4}\right)$. The greenhouse experiment was placed in a completely randomized design (Supp. Tab. 1) at temperatures from 7.7 to $37.2{ }^{\circ} \mathrm{C}$ (mean: $20.4{ }^{\circ} \mathrm{C}$ ) and a relative humidity of 16.9 to $83.1 \%$ (mean: $57.4 \%$ ). 
Table 1 Basic properties of the studied soils

\begin{tabular}{lccccccccccc}
\hline Soil & $\mathrm{pH}^{\mathrm{a}}$ & Clay & Sand & Silt & \multicolumn{1}{l}{$\mathrm{OC}$} & \multicolumn{1}{c}{$\mathrm{N}_{\mathrm{t}}^{\mathrm{b}}$} & $\mathrm{P}^{\mathrm{c}}$ & $\mathrm{K}^{\mathrm{c}}$ & $\begin{array}{c}\mathrm{Fe}^{\mathrm{d}} \\
\mathrm{Mn}^{\mathrm{d}}\end{array}$ & $\mathrm{Cu}^{\mathrm{e}}$ \\
\hline $\mathrm{L}$ & 4.95 & 7.8 & 66.4 & 25.8 & 16.4 & 1.66 & 87 & 129 & 279 & 64 & 5.2 \\
$\mathrm{D}$ & 7.45 & 16.8 & 28.6 & 54.6 & 17.6 & 1.79 & 122 & 402 & 185 & 413 & 18.6 \\
\hline
\end{tabular}

${ }^{\mathrm{a}}$ In $0.01 \mathrm{M} \mathrm{CaCl}_{2}$

${ }^{\mathrm{b}}$ Total nitrogen

${ }^{\mathrm{c}}$ In CAL—calcium acetate lactate

${ }^{\mathrm{d}}$ In EDTA—ethylenediaminetetraacetic acid

${ }^{\mathrm{e}} \mathrm{In} \mathrm{AR}$ - aqua regia
Since the presence of nitrate may decrease root nodulation and might have accumulated through excess mineralization during pot preparation (Broos et al. 2004), nitrate was leached with water by flushing the pots two times (one week in between) with an amount equivalent to $200 \%$ of the maximum water holding capacity (WHC).

Two weeks after leaching, a commonly used fungicide (Funguran Progress ${ }^{\circledR}$, Spiess-Urania, Hamburg, Germany), containing $53.7 \% \mathrm{Cu}(\mathrm{OH})_{2}$, was applied as a suspension in water onto the topsoil (Supp. Fig. 2) to reach 90\% WHC in concentrations of $0,0.05,0.1,0.2,0.5,1.5$ and $5 \mathrm{~g} \mathrm{Cu} \mathrm{kg}^{-1}$ soil $\mathrm{dw}$ with five replicates per concentration. One week after spiking, topsoils were scarified and inoculated with various rhizobial strains (Feldsaaten Freudenberger, Krefeld, Germany). On the 8th of May, two weeks after application of the fungicide, ten seeds of $M$. sativa cultivar. Plato (Feldsaaten Freudenberger) were sown per pot after inoculating the seeds with rhizobia to ensure nodulation. The plant number was reduced when the first four plants reached a height of 15 to $20 \mathrm{~cm}$.

\section{Soil analyses}

Pots were sampled over the whole height on the 14th and on the 92nd DAS with a 1-cm stainless steel auger (Supp. Fig. 3 ) and sieved to $\leq 2 \mathrm{~mm}$ immediately for microbial analyses (Keiblinger et al. 2018). Table 1 shows the basic topsoil properties according to Austrian standards (OENormL1061-2 2002; OENorm-L1079 1999; OENorm-L1085 2009; OENorm-L1095 2002) prior to sampling them in the field. The soil pH (OENorm-L1083 2006) was measured with $2 \mathrm{~g}$ of air-dried soil in $25 \mathrm{~mL} 0.01 \mathrm{M} \mathrm{CaCl}_{2}$ using a pH meter (pH 537, WTW GmbH Weilheim, Germany). Briefly, the organic carbon and total nitrogen according to (Brandstätter et al. 2013) was determined using a TOC/TN analyser (TOC-V CPHE200V, Shimadzu Corporation, Kyoto, Japan). Plant available phosphorus and potassium (OENormL1087 2004) were extracted with calcium acetate lactate. Potassium was determined in an atomic absorption spectrometer (AAS, Perkin Elmer 2100, MA, US) and phosphorus was measured spectro-photometrically using the molybdate blue staining method (Schinner et al. 1996).

Air-dried soil samples were used for $\mathrm{Cu}$ analyses in ethylenediaminetetraacetic acid- (EDTA) and $\mathrm{CaCl}_{2}$-extracts for both samplings, while $\mathrm{Cu}$ in diffusive gradients in thin films (DGT) was performed only for the second sampling.

\section{Copper analyses in soil extracts}

Samples of $5 \mathrm{~g}$ air-dried soil were extracted with $50 \mathrm{~mL} 0.05 \mathrm{M}$ Na-EDTA, shaken for $2 \mathrm{~h}$ and filtered (Munktell 14/N). Solutes were measured in flame-AAS (AAnalyst 400, Perkin Elmer) and correspond to the organically complexable amount of $\mathrm{Cu}$ (OENorm-L1089 2005).

Neutral salt $\mathrm{Cu}$ extracts were prepared with $2.5 \mathrm{~g}$ airdried soil and $50 \mathrm{~mL} 0.01 \mathrm{M} \mathrm{CaCl}_{2}$, corresponding to the easily soluble amount of $\mathrm{Cu}$ (Houba et al. 2000). The soil was equilibrated in solution overnight and shaken on the following day for $3 \mathrm{~h}$, prior to filtration and measurement with flame-AAS (PineAAcle 900T, Perkin Elmer).

\section{Copper quantification with the diffusive gradients in thin films technique (DGT)}

DGT is an infinite sink approach, interpreting the concentration $\mathrm{C}_{\mathrm{DGT}}$ as the time-averaged concentration of $\mathrm{Cu}$ at the interface of soil solution and DGT device. Free $\mathrm{Cu}$ ions are supplied by desorption from the soil solid phase and by mass flow or diffusion as well as dissociation of labile complexes in soil solution and within the diffusive gel of the DGT piston (Degryse et al. 2009; Harper et al. 1998).

Following Zhang (2005), the DGT sampling pistons consisted of $25-\mathrm{mm}$ plastic sockets covered by a $400-\mu \mathrm{m}$ thin Chelex 100 (sodium form, Sigma Aldrich) resin gel disc, an $800-\mu \mathrm{m}$ thick polyacrylamide diffusive gel disc, covered by a $150-\mu \mathrm{m}$ polyether sulfone membrane with $0.45 \mu \mathrm{m}$ mesh (Sartorius). A cap with a soil contact window of $\varnothing 20 \mathrm{~mm}$ kept these layer in place.

Soil samples were wetted to $60 \%$ WHC and incubated air tight for $24 \mathrm{~h}$ at $20^{\circ} \mathrm{C}$. Afterwards, the water content 
was raised to $90 \%$ WHC and DGT were deployed for $24 \mathrm{~h}$. The resin gels were eluted in $1 \mathrm{M} \mathrm{HNO}_{3}$ and analyzed by ICP-MS (ELAN DRL-e SIEX, Perkin Elmer) with ${ }^{115}$ In as internal standard and 103 to $104 \%$ element recovery for $\mathrm{Cu}$.

The concentration $C_{\mathrm{DGT}}\left(\mathrm{nmol} \mathrm{cm}{ }^{-3}\right)$ was calculated by the mass of metal $M$ (nmol) bound by the resin gel and the diffusion layer thickness $\Delta g(0.095 \mathrm{~cm})$, related to the diffusion coefficient $D_{\mathrm{w}}$ of $\mathrm{Cu}$ in water $\left(5.29 \times 10^{-6} \mathrm{~cm}^{2} \mathrm{~s}^{-1}\right)$ and the deployment time $t(\mathrm{~s})$ as well as the exposing area of the DGT device $A\left(\mathrm{~cm}^{2}\right)$.

$$
C_{\text {DGT }}=M \times \frac{\Delta g}{D_{\text {w }} \times t \times A}
$$

Whereas the mass of metal $M$ was calculated from the concentration determined in the eluate $\left(\mu \mathrm{g} \mathrm{cm}^{-3}\right)$ and the volume of the eluate $V_{\text {eluate }}$ as well as of the resin disc $V_{\text {disc }}$ $\left(\mathrm{cm}^{3}\right)$, with further correction for elution efficiency using a recovery factor $f_{\text {recovery }}$ of 0.82 .

$\mathbf{M}=\frac{\mathrm{c}_{\text {eluate }} \times\left(V_{\text {eluate }}+V_{\text {disc }}\right)}{f_{\text {recovery }}}$

\section{Plant analyses}

Measurements of shoot height $(\mathrm{cm})$, chlorophyll density (SPAD-502PLUS, Konica Minolta Optics Inc., Osaka, Japan) and counting of internodial distances, ramification and flowering were conducted between the $81^{\text {st }}$ and the $84^{\text {th }}$ day after sowing (DAS), while plants were harvested at the $101^{\text {st }}$ and $102^{\text {nd }}$ DAS.

Samples of shoots, roots and nodules were dried at $70{ }^{\circ} \mathrm{C}$ to constant weight and ground. Roots and nodules were washed carefully before drying.

An amount of $0.2 \mathrm{~g}$ oven dried roots, shoots or nodules was digested with $10 \mathrm{~mL}$ of $65 \%$ nitric- and $70 \%$ perchloric acid in a ratio of $6: 1(\mathrm{v} / \mathrm{v})$, filtered (Whatman 589/2) and $\mathrm{Cu}$ was analyzed in a graphite furnace (HGA 900, Perkin Elmer) AAS (AAS, AAnalyst 400).

\section{Nitrogenase activity}

The potential nitrogenase activity was assessed using acetylene reduction assays (ARA) by sampling ten nodules of each pot at plant harvest. According to Quilliam et al. (2013) and Zechmeister-Boltenstern (1993), 20-mL headspace vials were filled with $2 \mathrm{~cm}^{3}$ washed and calcined fine granular sea sand and $1.55 \mathrm{~mL}$ of isotonic Ringer solution, containing, $2.25 \mathrm{mM} \mathrm{Ca}{ }^{2+}, 155.7 \mathrm{mM}$ $\mathrm{Cl}^{-}, 4 \mathrm{mMK}^{+}$and $147.2 \mathrm{mM} \mathrm{Na}^{+}$for preventing an osmotic shock, as well as $4 \mathrm{~g}$ glucose $\mathrm{L}^{-1}$ to avert substrate limitations (Supp. Fig. 4-5).
Acetylene replaced $10 \%$ of the headspace volume and after $24 \mathrm{~h}$ incubation at $20^{\circ} \mathrm{C}$, gas samples were analyzed in a gas chromatograph (Hewlett Packard 5890 Series II with Hewlett Packard 7694 Headspace Sampler, Wilmington, NC, USA) equipped with an Alumnia column (Agilent, Santa Clara, CA, USA) and a flame ionization detector (Hewlett Packard 6890). An external standard with $10 \mathrm{ppm}$ ethylene was used. The amount of produced ethylene was related to the nodule number and the nodule volume, measured with a microscope (Olympus SZX, 10UC 30 camera, 72 dpi, Olympus Corporation, Tokyo, Japan).

\section{Root nodule imaging}

A second experiment followed the toxicity experiment with a mixed soil sample of all five replicates from the previously contaminated silt loam $\left(0.5 \mathrm{~g} \mathrm{Cu} \mathrm{kg}^{-1}\right)$. The soil was filled into rhizotrons (Supp. Fig. 6) at $1.4 \mathrm{~g} \mathrm{~cm}^{-3}$ dry density and wetted to $100 \%$ WHC once. Rhizotrons were inclined to $10^{\circ}$ and equipped with 6-mm glass fiber wicks for passive watering. Six seedlings of $M$. sativa were pre-germinated for three days before transferring into the rhizotrons. Root nodules were harvested after ten weeks of growth and washed in Millipore water with $20 \mathrm{~s}$ ultrasound treatment at $10 \%$ energy-output on continuous mode (HD2200 with $200 \mathrm{~W}$, Bandelin electronics, Berlin, Germany). Nodules were frozen onto the cutting socket of a cryostat (CM3050, Leica, Bensheim, Germany) with liquid nitrogen and cut into $50-\mu \mathrm{m}$ longitudinal and radial sections The nodule sections were air dried onto object slides and measured out with a microscope (Olympus SZX, 10UC 30).

The spatial distribution of ${ }^{13} \mathrm{C},{ }^{63} \mathrm{Cu},{ }^{57} \mathrm{Fe},{ }^{97} \mathrm{Mo},{ }^{55} \mathrm{Mn}$, ${ }^{32} \mathrm{~S}$, and ${ }^{51} \mathrm{~V}$ within the sections was sampled by laser ablation (LA), using a neodymium doped yttrium aluminum garnet laser (NWR 193, New Wave Research, Fremont, CA, US) with a laser energy of $3.6 \mathrm{~mJ} \mathrm{~cm}^{-2}$ connected to an inductively coupled plasma - mass spectrometer (ICP-MS, ELEMENT XR, Thermo Scientific, Bremen, Germany) with $\mathrm{Ar}$ and $\mathrm{He}$ as carrier gasses. Root nodule images were generated by ablating parallel lines from the nodule surface. The resolution of $9.95 \times 21.14 \mu \mathrm{m}$ for the longitudinal section and $9.95 \times 25.49 \mu \mathrm{m}$ for the radial section was determined by the spot size of $10 \mu \mathrm{m}$, the scan speed of $5 \mu \mathrm{m} \mathrm{s}^{-1}$ and the dwell time of $1.99 \mathrm{~s}$. Therefore, the counts of each data point of the scanned line consisted of 40 laser shots.

\section{Data evaluation}

Data processing and LA-ICP-MS image generation was performed in R (R-Development-Core-Team 2015). The Tukey's HSD (Honestly Significant Difference) test was used for identifying differences at $p<0.05$ between treatments and for determining the concentration with the first 
significant response, i.e. the lowest observed adverse effect level (LOAEL). The Welch test was used for differences between sampling times. Freundlich coefficients and the effective concentration for harvest losses of $50 \%\left(\mathrm{EC}_{50}\right)$ were calculated by regressions performed with mean values, with the root mean square error (RMSE) describing the goodness of fit. The RMSE was normalized on the value range into the normalized root mean square error (NRMSE) for comparing models with different variables.

$\mathrm{y}=\mathrm{K}_{\mathrm{F}} \times \mathrm{x}^{\frac{1}{\mathrm{n}}}$

The Freundlich equation estimates the resupply of $\mathrm{Cu}$ in $x\left(\mathrm{~m} \mathrm{~L} \mathrm{~L}^{-1}\right)$ from a solid or adsorbed pool, i.e. from soil and labile complexes $y\left(\mathrm{mg} \mathrm{kg}^{-1}\right)$. The parameter $\mathrm{n}$ shapes the isotherm and $K_{\mathrm{F}}\left(\mathrm{L} \mathrm{kg}^{-1}\right)$ is a constant for the adsorbed amount at a mobile fraction of $1 \mathrm{mg} \mathrm{kg}^{-1}$ (Freundlich 1909). The isotherms in our study are not identical to isotherms of adsorption experiments as we used $\mathrm{C}_{\mathrm{DGT}}-\mathrm{Cu}$ instead of the solution concentration and EDTA-extractable $\mathrm{Cu}$ as the adsorbed fraction.

\section{Results}

\section{Availability of copper by diffusive gradients in thin films and soil extracts}

Both soils showed strong increases in $\mathrm{C}_{\mathrm{DGT}} \mathrm{Cu}, \mathrm{CaCl}_{2^{-}}$ extractable $\mathrm{Cu}$ and EDTA-extractable $\mathrm{Cu}$ with increasing fungicide application (Supp. Tab. 2). The EDTA-Cu and $\mathrm{C}_{\mathrm{DGT}}-\mathrm{Cu}$ concentrations were consistently increasing along application rates with the first significant increase at $1.5 \mathrm{~g} \mathrm{~kg}^{-1}$. The ratio of the Freundlich coefficients $\mathrm{K}_{\mathrm{F}}$ (Fig. 1, Supp. Fig. 7) indicated 5.09 to 5.34 (mean: 5.21) more bioavailable $\mathrm{Cu}$ present in the acidic soil. In another way, ratios (data not shown) of EDTA-Cu and $\mathrm{C}_{\mathrm{DGT}}-\mathrm{Cu}$ indicated 4.6 to 5.6 (mean: 5.1) times more diffusive resupply and hence, higher plant-availability in soil $\mathrm{L}$.

The EDTA- and $\mathrm{CaCl}_{2}$-extractable $\mathrm{Cu}$ did not differ between soils, whereas the $\mathrm{CaCl}_{2}-\mathrm{Cu}$ showed a more dynamic pattern as it increased steadily with application rates only in soil $\mathrm{L}$ at the first sampling. At the second sampling, the 0.05 and $0.1 \mathrm{~g} \mathrm{~kg}^{-1}$ treatments showed marginally lower concentrations than the control. The same was the case for the alkaline soil D for both samplings in the $0.05,0.1$ and $0.2 \mathrm{~g} \mathrm{~kg}^{-1}$ treatments.

\section{Soil pH}

The soil $\mathrm{pH}$ (Table 2) of the first sampling consistently increased with $\mathrm{Cu}$ application, while the control showed slightly higher $\mathrm{pH}$ than the lower three treatments of soil $\mathrm{L}$

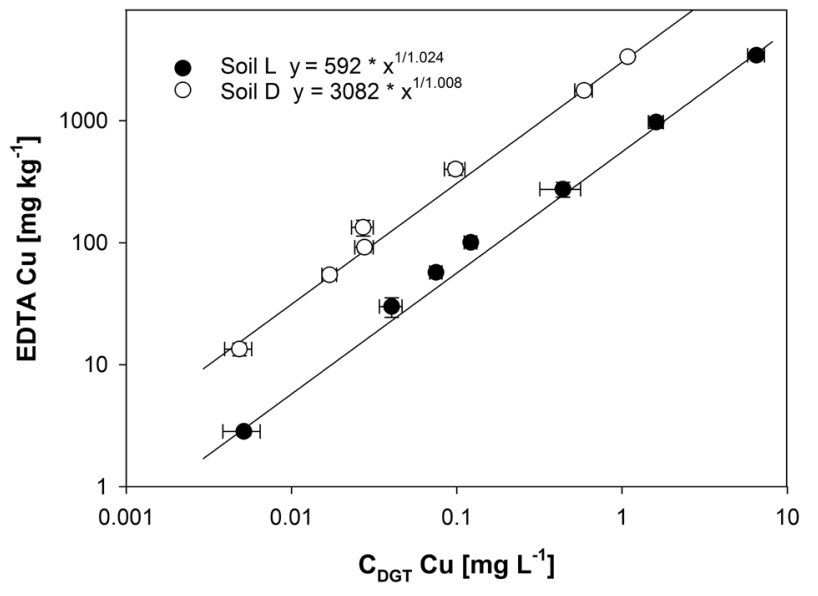

Fig. 1 Relationship of $0.05 \mathrm{M}$ EDTA-extractable $\mathrm{Cu}$ and $\mathrm{Cu}$ in diffusive gradients in thin films on the $92^{\text {nd }}$ day after sowing, according to Freundlich isotherms. The $\mathrm{R}^{2}$ was above 0.999 with $p<0.001$ for both soils. The error bars represent standard errors $(n=5)$. The normalized root mean square error was $2.8 \%$ for soil $\mathrm{L}$ and $1.6 \%$ for soil $\mathrm{D}$

Table 2 Soil $\mathrm{pH}\left(0.01 \mathrm{M} \mathrm{CaCl}_{2}\right)$ at the first and second sampling on the $14^{\text {th }}$ and $92^{\text {nd }}$ day after sowing, respectively, and the decrease in proton concentration from the first to the second sampling

\begin{tabular}{|c|c|c|c|c|}
\hline soil & $\begin{array}{l}\mathrm{Cu} \\
\text { spiked } \mathrm{g} \\
\mathrm{kg}^{-1}\end{array}$ & 1. $\mathrm{pH} \pm \mathrm{SEM}$ & 2. $\mathrm{pH} \pm \mathrm{SEM}$ & $\begin{array}{l}{\left[\mathrm{H}^{+}\right] \text {decrease } \mathrm{nM} \pm} \\
\text { SEM }\end{array}$ \\
\hline \multirow[t]{7}{*}{$\mathrm{L}$} & 0.00 & $4.82 \pm 0.03 c$ & $5.04 \pm 0.19 b$ & $2.74 \pm 4.20$ \\
\hline & 0.05 & $4.75 \pm 0.01 \mathrm{c}$ & $5.40 \pm 0.10 \mathrm{ab}$ & $13.5 \pm 1.55^{* *}$ \\
\hline & 0.10 & $4.79 \pm 0.01 \mathrm{c}$ & $5.52 \pm 0.12 \mathrm{ab}$ & $12.6 \pm 0.88^{*}$ \\
\hline & 0.20 & $4.81 \pm 0.02 c$ & $5.30 \pm 0.08 b$ & $10.1 \pm 1.41^{* *}$ \\
\hline & 0.50 & $4.85 \pm 0.03 c$ & $5.48 \pm 0.09 \mathrm{ab}$ & $10.6 \pm 1.21 * * *$ \\
\hline & 1.50 & $5.07 \pm 0.04 b$ & $5.52 \pm 0.11 \mathrm{ab}$ & $5.12 \pm 1.16$ \\
\hline & 5.00 & $5.54 \pm 0.07 \mathrm{a}$ & $5.90 \pm 0.07 \mathrm{a}$ & $1.72 \pm 0.57 *$ \\
\hline \multirow[t]{7}{*}{ D } & 0.00 & $7.46 \pm 0.09 b c$ & $7.10 \pm 0.04 c$ & $-0.043 \pm 0.009 *$ \\
\hline & 0.05 & $7.29 \pm 0.01 \mathrm{c}$ & $7.22 \pm 0.02 b c$ & $-0.010 \pm 0.003$ \\
\hline & 0.10 & $7.30 \pm 0.01 \mathrm{c}$ & $7.21 \pm 0.02 b c$ & $-0.011 \pm 0.002$ \\
\hline & 0.20 & $7.34 \pm 0.01 \mathrm{c}$ & $7.19 \pm 0.02 b c$ & $-0.018 \pm 0.003 *$ \\
\hline & 0.50 & $7.43 \pm 0.01 b c$ & $7.32 \pm 0.02 b$ & $-0.010 \pm 0.003$ \\
\hline & 1.50 & $7.59 \pm 0.03 \mathrm{ab}$ & $7.76 \pm 0.02 a$ & $0.008 \pm 0.002 * *$ \\
\hline & 5.00 & $7.68 \pm 0.02 a$ & $7.64 \pm 0.05 a$ & $-0.002 \pm 0.002$ \\
\hline
\end{tabular}

Different lower case letters following standard errors (SEM, $n=5$ ) indicate significant differences between treatments within each soil and asterisks indicate significant differences between the two sampling times

*Significant with $p<0.05$

**Significant with $p<0.01$

***Significant with $p<0.001$

and the lower four treatments of soil D. However, the first significant increase was at $1.5 \mathrm{~g} \mathrm{~kg}^{-1}$ in soil $\mathrm{L}$ and at $5 \mathrm{~g} \mathrm{~kg}^{-1}$ in soil $\mathrm{D}$, while the $\mathrm{pH}$ correlated positively with soil and plant $\mathrm{Cu}$ concentrations ( $p<0.05$; Supp. Tab. 3). Comparing 
between the two samplings, the $\mathrm{pH}$ in soil $\mathrm{L}$ increased in all treatments, but most strongly in the treatments with plant growth and in the highest treatment. The decline of protons in the $0.05-0.5 \mathrm{~g} \mathrm{~kg}^{-1}$ treatments of soil L was 2-fold to 7-fold compared with the highest two treatments, revealing that plants alkalinized the soil. Nevertheless, the difference between the sampling times was not significant at $1.5 \mathrm{~g} \mathrm{~kg}^{-1}$. In soil $\mathrm{D}$, a slight acidification took place in every treatment, except at $1.5 \mathrm{~g} \mathrm{~kg}^{-1}$, where plant growth was strongly diminished and the $\mathrm{pH}$ significantly increased from the first to the second sampling.

\section{Biomass production of Medicago sativa}

At 101 to 102 DAS, biomass production was generally higher in the alkaline soil (Fig. 2). But the biomass was in contrast to soil $\mathrm{Cu}$ and $\mathrm{pH}$ data more variable along the treatments and not constantly decreasing. The root and shoot biomass of soil L increased slightly in the $0.05 \mathrm{~g} \mathrm{~kg}^{-1}$ treatment to further decline. In soil $\mathrm{D}$, however, the biomass production decreased in the first treatment to increase further up to the $0.5 \mathrm{~g} \mathrm{~kg}^{-1}$ treatment. The LOAEL of shoot and root biomass was 0.5 and $0.1 \mathrm{~g} \mathrm{Cu} \mathrm{kg}^{-1}$ soil in soil $\mathrm{L}$ and $1.5 \mathrm{~g} \mathrm{~kg}^{-1}$ in soil $\mathrm{D}$, with shoot biomass decreasing to approximately $10 \%$ and $36 \%$, respectively, and root biomass to $40 \%$ and $26 \%$, respectively, relative to the control. But, related to the highest yield, the shoot biomass in soil L decreased already in the $0.1 \mathrm{~g} \mathrm{~kg}^{-1}$ treatment.

Fitting root and shoot biomass (Supp. Fig. 8) to extractable $\mathrm{Cu}$ presented $\mathrm{C}_{\mathrm{DGT}^{-}} \mathrm{Cu}$ being superior in soil $\mathrm{D}$, but $\mathrm{CaCl}_{2}-\mathrm{Cu}$ fitted better in soil L. Regressions with EDTA-Cu showed the smallest error (i.e. 10 to $20 \%$ ) for root nodule biomass in both soils.

The LOAEL for root nodule biomass was at $0.5 \mathrm{~g} \mathrm{Cu} \mathrm{kg}^{-1}$ in soil $\mathrm{L}$ and at $1.5 \mathrm{~g} \mathrm{Cu} \mathrm{kg}^{-1}$ in soil $\mathrm{D}$, with biomass decreasing to $25 \%$ and $27 \%$, respectively, relative to the control. For the nodule number (Supp. Tab. 4), the LOAEL was at $0.1 \mathrm{~g} \mathrm{Cu} \mathrm{kg}^{-1}$ in soil $\mathrm{L}$ and at $1.5 \mathrm{~g} \mathrm{Cu} \mathrm{kg}^{-1}$ in soil $\mathrm{D}$, with decreases to $34 \%$ and $15 \%$, respectively. In both soils, the nodule number and biomass were positively correlated with shoot and root biomass and with the growth parameters and negatively with $\mathrm{CaCl}_{2}$ - $\mathrm{Cu}$ at the first sampling, while correlating negatively with all soil $\mathrm{Cu}$ analyses in soil $\mathrm{D}$. Interestingly, both nodule parameters decreased more strongly than the below- or above ground biomass production.

The growth parameters (Supp. Fig. 9) were different between the soils, but seemed to be less affected by $\mathrm{Cu}$. Shoot height, internodial distances and ramification showed the LOAEL at $0.5 \mathrm{~g} \mathrm{~kg}^{-1}$ in soil L and at $5 \mathrm{~g} \mathrm{~kg}^{-1}$ in soil D. Also the flowering was affected in this treatment in soil D. The chlorophyll density was responsive at $1.5 \mathrm{~g} \mathrm{~kg}^{-1}$ in soil $\mathrm{L}$ and at $5 \mathrm{~g} \mathrm{~kg}^{-1}$ in soil $\mathrm{D}$. All these parameters were positively correlated with each other and with plant biomass in both soils $(p<0.05)$. Also all $\mathrm{Cu}$ measurements in both soils, except $\mathrm{C}_{\mathrm{DGT}}-\mathrm{Cu}$ in soil $\mathrm{L}$ correlated with the growth factors. The shoot height and SPAD values of soil $\mathrm{L}$ were correlated with $\mathrm{CaCl}_{2}-\mathrm{Cu}$ at the first sampling only.

\section{Accumulation and translocation of copper in Medicago sativa}

The shoot and root $\mathrm{Cu}$ concentrations (Supp. Fig. 10) of the 1.5 and $5 \mathrm{~g} \mathrm{~kg}^{-1}$ treatments needed to be analyzed as pooled samples of the whole treatment, since plant growth strongly diminished. In both soils, we observed slightly decreasing shoot $\mathrm{Cu}$ compared to the control up to $0.1 \mathrm{~g} \mathrm{~kg}^{-1}$ in soil $\mathrm{L}$ and until $0.2 \mathrm{~g} \mathrm{~kg}^{-1}$ in soil $\mathrm{D}$, but not significantly. Shoot $\mathrm{Cu}$ increased at $0.5 \mathrm{~g} \mathrm{~kg}^{-1}$ in soil $\mathrm{L}$ and at $1.5 \mathrm{~g} \mathrm{~kg}^{-1}$ in soil D. The root $\mathrm{Cu}$ concentrations were continuously increasing with application rate and higher in the acidic soil L, but they were statistically similar in both soils. Both, shoot and root $\mathrm{Cu}$ concentrations were correlated with soil $\mathrm{Cu}$, while $\mathrm{CaCl}_{2}-\mathrm{Cu}$ at the second sampling showed the highest correlation coefficient in soil $\mathrm{D}$. In soil $\mathrm{L}$, shoot $\mathrm{Cu}$ was stronger correlated with $\mathrm{C}_{\mathrm{DGT}}-\mathrm{Cu}$ and root $\mathrm{Cu}$ with EDTA$\mathrm{Cu}$ at the second sampling. In regressions of both soils (Supp. Tab. 5), $\mathrm{C}_{\mathrm{DGT}^{-} \mathrm{Cu}}$ presented the smallest error (NRMSE: $4.3 \%$ ) for shoot $\mathrm{Cu}$ and the $\mathrm{CaCl}_{2}-\mathrm{Cu}$ concentrations at the second sampling seemed to result in nonlinear regressions superior for root and nodule $\mathrm{Cu}$.

The ratio of $\mathrm{Cu}$ in shoots and roots (Supp. Tab. 4) was similar in both soils and highest in the control, resulting in ratios of 0.77 in soil $\mathrm{L}$ and 1.08 in soil $\mathrm{D}$, with mostly higher ratios in soil $\mathrm{D}$. The $\mathrm{Cu}$ withdrawal (Supp. Tab 6) by below- and above ground biomass was overall higher in soil D, except for roots at $0.05 \mathrm{~g} \mathrm{~kg}^{-1}$. Taking both aspects together presented a stronger translocation of $\mathrm{Cu}$ into the shoots of plants from soil $\mathrm{D}$, which increased up to $0.5 \mathrm{~g}$ $\mathrm{kg}^{-1}$ as the biomass.

Assuming the $\mathrm{CaCl}_{2}-\mathrm{Cu}$ to be the relevant fraction for plant uptake, the root uptake based on $4.8 \mathrm{~kg}$ soil $\mathrm{dw}$ accounted for $102 \%$ and $18 \%$ in the 0.05 and $0.1 \mathrm{~g} \mathrm{~kg}^{-1}$ treatment of soil $\mathrm{L}$, respectively, of the decrease in $\mathrm{CaCl}_{2}$ $\mathrm{Cu}\left(-31 \mu \mathrm{g} \mathrm{kg}^{-1}\right.$ in both treatments) compared to the control (Supp. Tab. 6). Since the shoot withdrawal decreased in response to $\mathrm{Cu}$ exposure, the whole plant uptake only accounted for $68 \%$ in the $0.05 \mathrm{~g} \mathrm{~kg}^{-1}$ treatment. In the alkaline soil, higher plant growth increased $\mathrm{Cu}$ withdrawals, while root uptake in the $0.05,0.1$ and $0.2 \mathrm{~g} \mathrm{~kg}^{-1}$ treatments accounted for 33, 80 and $98 \%$, respectively, of the decreases in $\mathrm{CaCl}_{2}-\mathrm{Cu}\left(-48,-48\right.$ and $\left.-34 \mu \mathrm{g} \mathrm{kg}^{-1}\right)$, shoot uptake for $6 \%$ in the $0.2 \mathrm{~g} \mathrm{~kg}^{-1}$ treatment, and the whole plant uptake for 74 and $105 \%$ in the 0.1 and $0.2 \mathrm{~g} \mathrm{~kg}^{-1}$ treatment, respectively. On the other hand, the increases of $\mathrm{CaCl}_{2}-\mathrm{Cu}$ in the following two treatments $(+117$ and $+444 \mu \mathrm{g} \mathrm{kg}^{-1}$ ) were compensated through root uptake by 

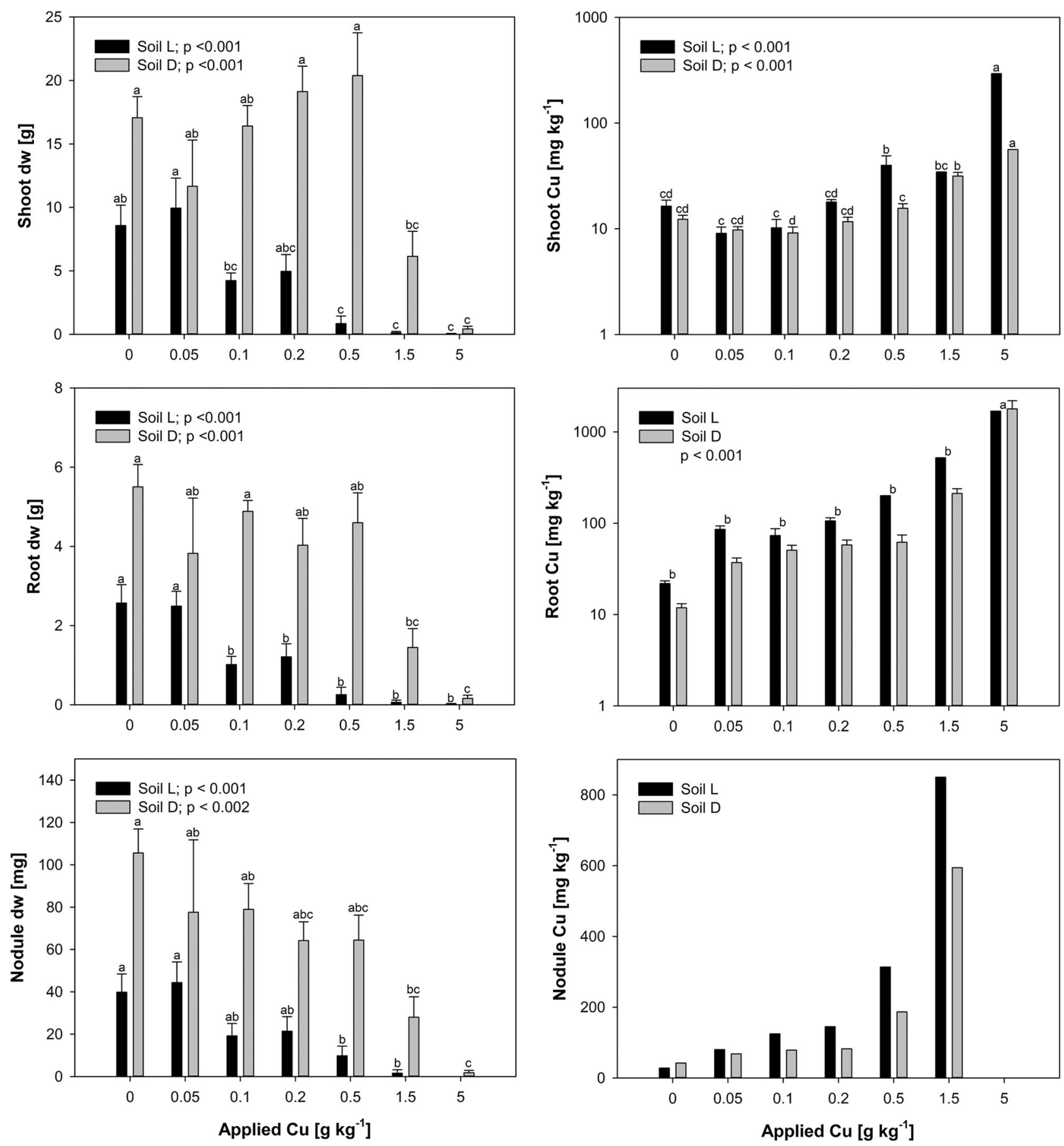

Fig. 2 Biomass dry weights (dw) of shoot (top left), root (middle left) and root nodules (bottom left) per pot and $\mathrm{Cu}$ concentrations of shoot (top right), root (middle right) and root nodules (bottom right) after 101/102 days after sowing. Root $\mathrm{Cu}$ concentrations did not differ between soils. Root nodule $\mathrm{Cu}$ concentrations are single values of

$32 \%$ and $10 \%$ and through plant uptake by nearly $50 \%$ and $9 \%$, respectively. In the acidic soil, root compensation was less than $5 \%$ of the increase in $\mathrm{CaCl}_{2}-\mathrm{Cu}$.

The contribution of root nodules to the changes in $\mathrm{CaCl}_{2}$ $\mathrm{Cu}$ were neglectable, caused by their low weight, as the uptake of roots and shoots exceeded nodule uptake by mean

pooled samples within each treatment. Different letters above standard errors $(n=5)$ indicate significant differences between treatments within each soil, except for root $\mathrm{Cu}$ concentrations as soils were not significantly different

42-45 fold in soil L and 30-34 fold in soil D. The nodule $\mathrm{Cu}$ concentrations of pooled samples per treatment increased according to $\mathrm{Cu}$ application and were correlated with soil $\mathrm{Cu}$ and root $\mathrm{Cu}$. Interestingly, the nodules obtained in average $42 \%$ higher $\mathrm{Cu}$ concentrations than roots from soil $\mathrm{L}$ and $137 \%$ in soil $\mathrm{D}$, respectively. 

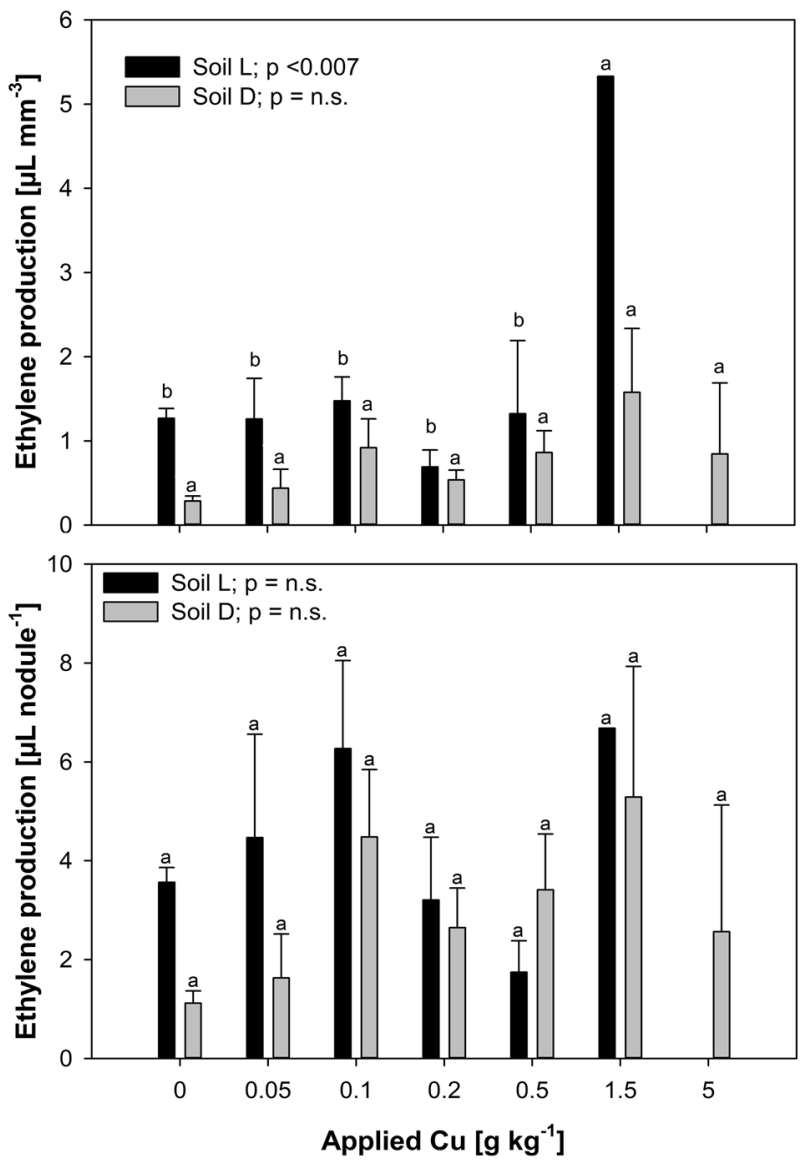

Fig. 3 Ethylene production through acetylene reduction by root nodules related to nodule size (top) and nodule number (bottom) 101/ 102 days after sowing. Different letters above standard errors $(n=5$, see Supp. Tab. 4) indicate significant differences between treatments within each soil. Ethylene production related to the nodule number was not significantly different between soils or treatments

\section{Nitrogen fixation and element distribution in root nodules}

The ARA reached from 0 to 5.33 (mean: 1.05) $\mu \mathrm{L}$ ethylene $\mathrm{mm}^{-3}$ nodule $^{-1}$ (Fig. 3) and was different between soils, whereas increased ethylene production was observed in the acidic soil L, compared with the alkaline soil D. However, if the highest ethylene production result in the $1.5 \mathrm{~g} \mathrm{Cu} \mathrm{kg}^{-1}$ treatment of soil L was excluded, because only one measurement of a cluster-like nodule was available, the ethylene production was not correlated with soil $\mathrm{Cu}$. Whereas inlusion of this measurement caused a positive correlation with nodule $\mathrm{Cu}$ in both soils and with soil $\mathrm{Cu}$ and $\operatorname{root} \mathrm{Cu}$ in soil $\mathrm{L}$.

Related to the nodule number, the ethylene production ranged from 0 to 12.8 (mean: 3.43) $\mu \mathrm{L}$ ethylene nodule ${ }^{-1}$ and was neither different between soils, nor between treatments and showed no systematic correlations. These results under consideration of the morphology of the nodules from the $1.5 \mathrm{~g} \mathrm{Cu} \mathrm{kg}^{-1}$ treatment in soil $\mathrm{L}$ justified the exclusion of the highest ethylene production result and the conclusion of no relation of the ARA with soil $\mathrm{Cu}$.

Chemical imaging of the radial nodule section (Fig. 4) yielded ${ }^{32} \mathrm{~S}$ mostly below detection limit. However, the absence of ${ }^{32} \mathrm{~S}$ or ${ }^{13} \mathrm{C}$ was not caused by a lack of matrix, as absolute counts of ${ }^{97} \mathrm{Mo}$ showed a fairly consistent distribution across the nodule. We mainly found ${ }^{63} \mathrm{Cu}$ and ${ }^{55} \mathrm{Mn}$ in the cortex, whereas ${ }^{57} \mathrm{Fe}$ and ${ }^{51} \mathrm{~V}$ occurred in very low amounts.

The longitudinal section of the nodule also contained ${ }^{55} \mathrm{Mn}$ mostly in the cortex. The meristem contained most of the ${ }^{63} \mathrm{Cu}$ and ${ }^{97} \mathrm{Mo}$, related to ${ }^{32} \mathrm{~S}$, while ${ }^{57} \mathrm{Fe}$, e.g. in nitrogenase, was homogenously distributed from the postmeristem, i.e. the infection zone, towards the root, while ${ }^{97} \mathrm{Mo}$ declined. Small amounts of ${ }^{51} \mathrm{~V}$ were found in the meristem and the ${ }^{32} \mathrm{~S}$-poor zone, which also contains leghemoglobin (Brennicke and Schopfer 2010). In the latter, the highest abundances of ${ }^{57} \mathrm{Fe},{ }^{51} \mathrm{~V},{ }^{63} \mathrm{Cu}$ and ${ }^{55} \mathrm{Mn}$ were found. Comparable results were achieved by single linescans from longitudinal section of other nodules (Supp. Fig. 11-12).

Absolute counts of the longitudinal section gave the same information, whereas higher intensities of ${ }^{63} \mathrm{Cu}$ and ${ }^{97} \mathrm{Mo}$ were found in the zone of $\mathrm{N}_{2}$-fixation, which contained the highest density of ${ }^{32} \mathrm{~S}$ and ${ }^{57} \mathrm{Fe}$.

\section{Discussion}

\section{The behavior of copper in soil}

The relation of EDTA-Cu to $\mathrm{C}_{\mathrm{DGT}}-\mathrm{Cu}$ showed more bioavailable $\mathrm{Cu}$ present in the acidic soil (Fig. 1). This indicates lower sorption capacity (Lair et al. 2006) for the fungicide in the acidic sandy soil $\mathrm{L}$ and stronger adsorption in the finer textured alkaline soil $\mathrm{D}$. The $\mathrm{pH}$, clay and silt contents of soil D could explain its stronger $\mathrm{Cu}$ sorption (Elbana and Selim 2011; Kabata-Pendias 2004; Lair et al. 2007; Lair et al. 2006; Lindsay 1979). In acidic soils, less pHdependent binding sites are available for adsorption onto $\mathrm{SOM}$, which governs $\mathrm{Cu}$ mobility to a large extend. Especially in alkaline environments, the precipitation as $\mathrm{Cu}$-carbonates, -oxides and -hydroxides as well as cupric ferrite strongly reduces $\left[\mathrm{Cu}^{2+}\right]$ activity (Lindsay 1979), while also the sorption onto mineral surfaces, e.g. Fe-, Al-, Mn-oxides and -hydroxides decreases $\mathrm{Cu}$ availability (Amelung et al. 2018; Lair et al. 2007; Lair et al. 2006; Wenzel et al. 2011).

\section{Plant responses affecting copper availability}

Plants prevent metal uptake from soil by immobilization through organic ligands or by influencing the $\mathrm{pH}$-dependent 
Fig. 4 Images of elemental distributions in root nodules of Medicago sativa as measured by LA-ICP-MS with abundances based on ${ }^{32} \mathrm{~S}$ distribution (top), absolute counts of elements in the longitudinal section (middle) and absolute counts in the radial section (bottom). Results are scaled on the maximum measured counts or ${ }^{32} \mathrm{~S}$-based ratio of each image for reasons of comparability. Labels in the micrograph indicate the cortex (I), meristem (II), infection zone (III), $\mathrm{N}_{2}$-fixing zone (IV) and the senescing zone $(\mathrm{V})$ followed by the root. The empty line in the longitudinal section resulted from a test run. The radial section was taken from another nodule and shows the cortex and cells. Blank cells correspond to values below the detection limit. The black bar corresponds to $160 \mu \mathrm{m}$

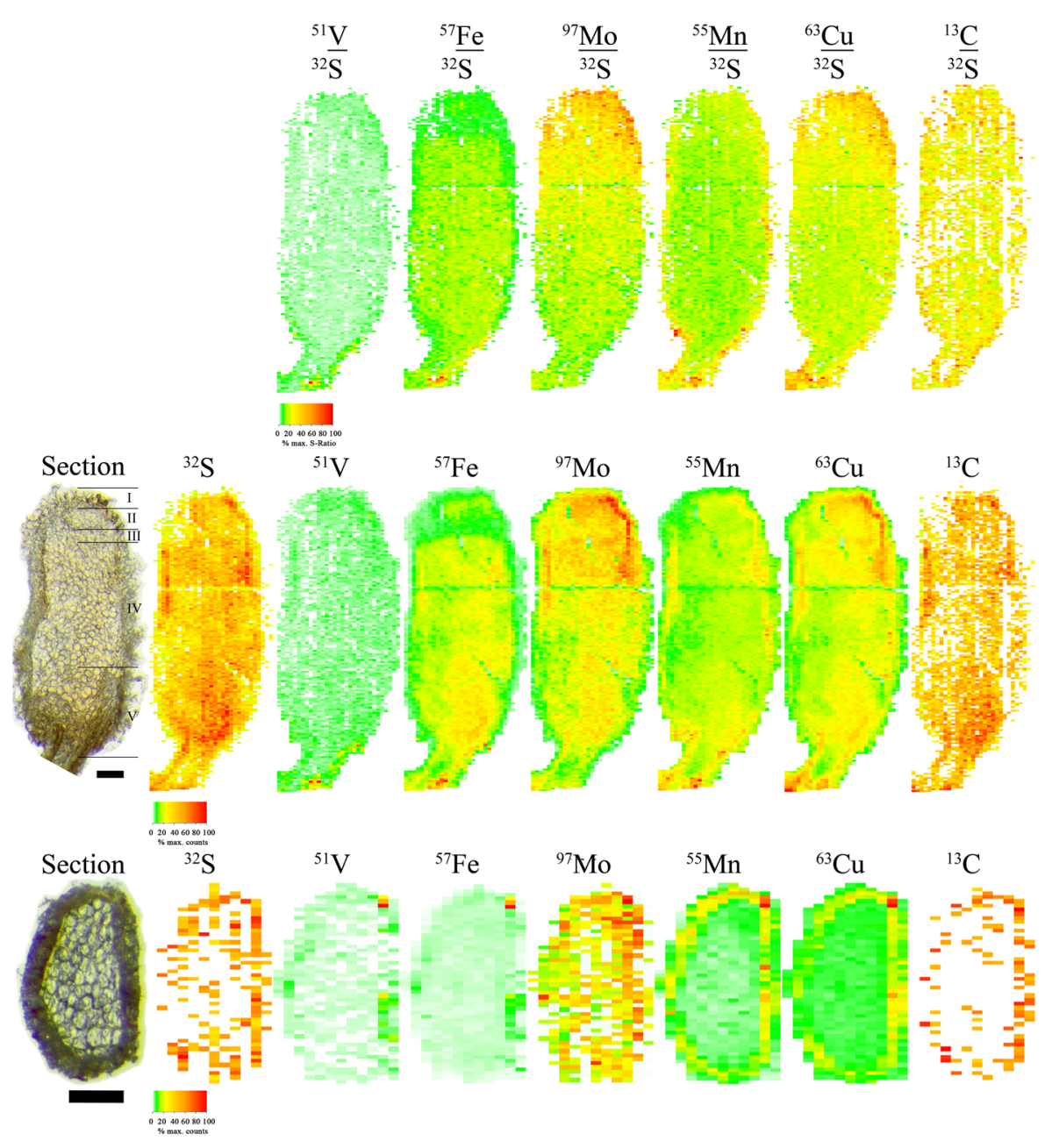

mobility by releasing protons or anions. The latter causes surface deprotonation of soil particles with variable charges, which decreases $\mathrm{Cu}$ mobility and therefore toxicity (Bravin et al. 2009; Cornu et al. 2007; Wenzel et al. 2011; White 2012).

The $\mathrm{pH}$ increased in the current study between the two samplings in the acidic soil (Table 2) indicating these rhizosphere processes. Wherease the increase in $\mathrm{pH}$ was observed for the whole pots and not only in the rhizosphere, where $\mathrm{pH}$ effects might have been much more pronounced, at least in the acidic soil (Michaud et al. 2007). Bravin et al. (2009) described for durum wheat increasing $\mathrm{pH}$ from 4.6 to 7.4 in a vineyard soil with $184 \mathrm{mg}$ total $\mathrm{Cu} \mathrm{kg}^{-1}$, reaching more than $6 \mathrm{~mm}$ into the rhizosphere. Increases of soil $\mathrm{pH}$ by $0.09-0.27$ units were observed by Cornu et al. (2007) with tomato on contaminated acidic vineyard soils with $\mathrm{pH}$ 4.3 and $43-47 \mathrm{mg} \mathrm{Cu} \mathrm{kg}^{-1}$ in EDTA. On calcareous soil ( $\mathrm{pH}$ 8.1-8.7 and 51-176 $\mathrm{mg} \mathrm{Cu} \mathrm{kg}^{-1}$ ), they observed $\mathrm{pH}$ decreases by $0.08-0.1$ units, while Tao et al. (2004) mentioned that a change by less than 0.5 units at a soil $\mathrm{pH}$ of 8.12 and $126 \mathrm{mg}$ total $\mathrm{Cu} \mathrm{kg}^{-1}$ does not affect $\mathrm{Cu}$ fractionation. However, decreasing the proton concentration in soil solution decreases $\left[\mathrm{Cu}^{2+}\right]$ activity and triggers sequestration and precipation as $\mathrm{Cu}$ minerals (Lindsay 1979) triggered by plants.

In the alkaline soil $\mathrm{D}$, the $\mathrm{pH}$ also increased with increasing $\mathrm{Cu}$ application, but was mostly lower at the second sampling indicating a slight acidification during plant growth. As the $\mathrm{pH}$ contrary increased with time at $1.5 \mathrm{~g} \mathrm{Cu} \mathrm{kg}^{-1}$, but not at the highest application rate, it can be concluded that plants facing $\mathrm{Cu}$ toxicity utilize rhizosphere alkalization even in alkaline environments.

\section{Root copper sorption capacity, translocation and physiological consequences}

Plant growth was more sensitive in soil $\mathrm{L}$, which revealed higher activity of $\mathrm{Cu}$ in acidic environments, whereas the growth factors representing stunted growth as indication of Cu toxicity (Díaz et al. 2001; Zorn et al. 2013) were less sensitive than the diminishing plant biomass.

The LOAEL for shoot biomass, i.e. 0.5 and $0.1 \mathrm{~g} \mathrm{Cu} \mathrm{kg}^{-1}$ soil in soil $\mathrm{L}$ and $1.5 \mathrm{~g} \mathrm{~kg}^{-1}$ in soil $\mathrm{D}$, was identical with the increase of shoot $\mathrm{Cu}$ in both soils, indicating root membrane 
damage and subsequent higher symplastic uptake (Cestone et al. 2012) followed by oxidative stress (Díaz et al. 2001; Halliwell and Gutteridge 1984). A comparable pattern was observed by Chen et al. (2013) for the relative root elongation of grapevine exposed to $1-25 \mu \mathrm{M}\left[\mathrm{Cu}^{2+}\right]$. The order of sensitivity according to $\mathrm{EC}_{50}$, i.e. the effective concentration for harvest losses of 50\%, (Supp. Fig. 8) followed nodule $>$ root $>$ shoot biomass in soil $\mathrm{D}$ and the opposite in soil $\mathrm{L}$. The corresponding $\mathrm{EC}_{50}$-concentrations are listed in Supp. Tab. 7. and in general, they exceeded the $\mathrm{EC}_{50}$ of Caetano et al. (2016).

In this context, the use of artificial rainwater might have influenced the uptake and overestimated the observed toxicity thresholds, since (i) $\mathrm{Ca}^{2+}$ is competing with $\mathrm{Cu}$ for sorption sites at the roots, causing less $\mathrm{Cu}$ uptake and toxicity alleviation (Degryse et al. 2009; Wenzel et al. 2011; $\mathrm{Wu}$ and Hendershot 2010) and (ii) besides $\mathrm{HPO}_{4}{ }^{2-}, \mathrm{SO}_{4}{ }^{2-}$ and $\mathrm{Cl}^{-}$are preferentially taken up by metal-exposed alfalfa plants for complexing free $\mathrm{Cu}$ ions (Peralta-Videa et al. 2002). Also, the fact that roots in compacted, potted soil grew preferentially at the pot-sided soil surfaces, might have lowered the observed thresholds.

Our data suggest the $\mathrm{CaCl}_{2}-\mathrm{Cu}$ concentrations to be directly affected by plants throught root uptake and translocation into above ground biomass(Supp. Tab. 6). Physiological consequences of root $\mathrm{Cu}$ sorption were similar in both soils, indicated by the ratios of shoot to root biomass and tissue $\mathrm{Cu}$ concentrations (Supp. Tab. 4). However, the capacity of the plant for $\mathrm{Cu}$ uptake without facing toxicity, represented by the plant withdrawal (Supp. Tab. 6), was higher in the alkaline soil $\mathrm{D}$, except at $0.05 \mathrm{~g} \mathrm{~kg}^{-1}$. Interestingly, more $\mathrm{Cu}$ was retained in roots under acidic growth condition, while plants from the alkaline soil translocated $\mathrm{Cu}$ to a larger extend into the shoot. Also the slight decrease in shoot $\mathrm{Cu}$ with increasing root $\mathrm{Cu}$ in response to application rates of up to $0.1 \mathrm{~g} \mathrm{~kg}^{-1}$ in soil $\mathrm{L}$ and up to $0.2 \mathrm{~g} \mathrm{~kg}^{-1}$ soil $\mathrm{D}$ indicates effective attenuation of $\mathrm{Cu}$ translocation into aerial parts (Michaud et al. 2007).

Adsorption to the root by influencing variable charges remains small compared to the absorbed amount (Degryse et al. 2012). However, root cell wall binding of up to $1 \mathrm{~g} \mathrm{~kg}^{-1}$ (Bravin et al. 2010) mainly controls Cu mobility in plants growing in contaminated media (Cestone et al. 2012; Michaud et al. 2007; Wenzel et al. 2011).

Especially in calcareous soil, root adsorption might be higher due to less proton competition for surface charges, with subsequent lower toxicity thresholds (Degryse et al. 2009; Michaud et al. 2007; Peralta-Videa et al. 2002). Tissue concentrations of $\mathrm{Cu}$ (Supp. Fig. 10) in this study were in the range of durum wheat (Bravin et al. 2010). Related to $\mathrm{CaCl}_{2}-\mathrm{Cu}$, tissue $\mathrm{Cu}$ in the alkaline soil was higher than in the acidic soil, as observed by Michaud et al. (2007). At the LOAEL for biomass yields, root and nodule
$\mathrm{Cu}$ concentrations were higher in the alkaline soil, while shoot $\mathrm{Cu}$ was lower than in the acidic soil. However, related on treatments or EDTA-extractable $\mathrm{Cu}$, all tissues from plants growing in the acidic soil contained more $\mathrm{Cu}$, as observed by Cornu et al. (2007).

\section{Copper influencing the nitrogen fixation}

The $\mathrm{N}_{2}$-fixation by root nodules was strongly diminished indirectly through their declining biomass and the root nodule number. As a consequence of impaired root development they appeared as the most responsive parameters to $\mathrm{Cu}$ in our study. They were remarkably reduced at $\mathrm{C}_{\mathrm{DGT}}-\mathrm{Cu}$ higher than $1.6 \mathrm{mg} \mathrm{L}^{-1}$ in this study, which is lower than the $10 \mathrm{mg} \mathrm{Cu} \mathrm{L}^{-1}$ solution concentration resulting in $97 \%$ inhibition of ARA, reported by Porter and Sheridan (1981).

However, ethylene production was not related to any soil extractable $\mathrm{Cu}$ fraction. The potential nitrogenase activity measured via ARA in this study (Fig. 3) was higher in the acidic soil. This is (i) $\mathrm{pH}$ dependent, as Porter and Sheridan (1981) reported highest values for ARA at $\mathrm{pH} 3$ and (ii) caused by higher $\mathrm{Fe}$ availability for $\mathrm{N}_{2}$-fixation (Bellenger et al. 2014; Brennicke and Schopfer 2010; White 2012).

Broos et al. (2004), who used ${ }^{15} \mathrm{~N}$ with clover, did observe metal toxicity on $\mathrm{N}_{2}$-fixation in a sewage sludge amended soil, whereas no differentiation could be made between direct detrimental effects of $\mathrm{Cu}, \mathrm{Zn}, \mathrm{Cd}$ and excess of mineral-N or co-contaminants. In metal salt amended soil, they showed depressed $\mathrm{N}_{2}$-fixation, if the host plant was not able to survive. Comparable results were obtained by Chaudri et al. (2008) for the population size of $R$. leguminosarum with sludge cake and metal salt spiked sewage sludge. Dahlin et al. (1997) showed decreases in auto- and heterotrophic $\mathrm{N}_{2}$-fixation in a long-term experiment free of crops with soils treated with metal contaminated sewage sludge and metal salts. Commonly, these authors reported $\mathrm{Cu}$ with the highest relative increase, compared to other metals, with negative correlation to the potential $\mathrm{N}_{2}$-fixation. However, no distinction between $\mathrm{pH}-$ effect, soil $\mathrm{N}$-increase and specific heavy metal response could be made. Contrary, population sizes of $R$. leguminosarum were not correlated with $\mathrm{Cu}$ and slightly increasing with higher metal salt addition (Dahlin et al. 1997).

In our study, the root nodules showed higher $\mathrm{Cu}$ uptake than roots, except for the $0.05 \mathrm{~g} \mathrm{~kg}^{-1}$ treatment in soil $\mathrm{L}$, without affecting nitrogenase activity. Higher internalization into nodules was also shown by Snowball et al. (1980) for up to $10 \mathrm{mg} \mathrm{Cu} \mathrm{kg}^{-1}$ in soil, and is caused by highaffinity metal chelating proteins, making nodules an important metal sink (González-Guerrero et al. 2016).

Our nodule images by LA-ICP-MS (Fig. 4) were in good agreement to Rodríguez-Haas et al. (2013). They also showed sporadic $\mathrm{Fe}$, and therefore nitrogenase in the infection zone 
and declining $\mathrm{Fe}$ concentrations in the senescence zone, with no $\mathrm{Fe}$ in the meristem and the epidermal layer.

High abundances of ${ }^{63} \mathrm{Cu}$ and ${ }^{97} \mathrm{Mo}$ in the meristem might be related to their involvement as cofactors in a number of enzymatic processes. These are condensed in regions of high metabolic activity (Arora et al. 2010; Hille et al. 1998; Preisig et al. 1996). The declining ${ }^{97} \mathrm{Mo} /{ }^{32} \mathrm{~S}$ ratios towards the root might indicate the preferential use of $\mathrm{Mo} / \mathrm{Fe}$-nitrogenase by younger symbiosomes, while older ones tend to use the alternative $\mathrm{Fe} / \mathrm{Fe}$ - or $\mathrm{V} / \mathrm{Fe}$-nitrogenase.

Likely due to high contents of leghemoglobin, the region close to the root seemed to buffer high levels of ${ }^{63} \mathrm{Cu},{ }^{55} \mathrm{Mn}$, ${ }^{57} \mathrm{Fe}$ and ${ }^{51} \mathrm{~V}$ compared to the whole nodule. Despite the possibility of inducing $\mathrm{ROS},{ }^{63} \mathrm{Cu}$ was present in the zone of $\mathrm{N}_{2}$-fixation. Therein, rhizobia metabolize $\mathrm{NO}_{3}{ }^{-}$, which is further reduced by the $\mathrm{Fe}$ - or Mo-containing $\mathrm{NO}_{3}{ }^{-}$-reductase to $\mathrm{NO}_{2}{ }^{-}$(Arora et al. 2010; Hille et al. 1998). Since $\mathrm{NO}_{2}{ }^{-}$is toxic to the nitrogenase, it must be reduced by $\mathrm{NO}_{2}{ }^{-}$-reductase, which contains $\mathrm{Cu}$ as core element. The supply of $\mathrm{Cu}$ could therefore elevate nitrogenase activity, which is supported by increasing activity of $\mathrm{NO}_{3}{ }^{-}$- and $\mathrm{NO}_{2}{ }^{-}$-reductase, uptake hydrogenase and acetylene reduction by a free living Sinorhizobium meliloti in yeast extract mannitol agar containing $6.35 \mathrm{~g} \mathrm{~L}^{-1} \mathrm{Cu}$ (Arora et al. 2010). These findings and considerations by chemical imaging illustrate the strong involvement of $\mathrm{Cu}$ during $\mathrm{N}_{2}$-fixation.

\section{Summary and conclusions}

This work reported plant responses in soil after application of a $\mathrm{Cu}$-based fungicide at moderate to very high concentrations, with the highest treatment being more strongly contaminated than former vineyards (Bravin et al. 2010; Michaud et al. 2007). We found more mobile $\mathrm{Cu}$ in an acidic sandy loam compared to an alkaline fine-textured silt loam. Depending on soil properties, notably $\mathrm{pH}$ and texture, the toxicity thresholds for alfalfa growth were much lower in the acidic soil and were in line with increases in plant tissue $\mathrm{Cu}$ concentrations. Our results also revealed the involvement of plant physiological responses affecting the mobility of $\mathrm{Cu}$ in these contaminated soils.

While this study could not achieve a positive or negative evaluation regarding effect of $\mathrm{Cu}$ on the enzymatic $\mathrm{N}_{2}$ fixation, it was thoroughly shown, that the nodule number and biomass was reduced, most likely as a consequence of impaired root development, at $0.1 \mathrm{~g} \mathrm{Cu} \mathrm{kg}^{-1}$ in the acidic soil and at $1.5 \mathrm{~g} \mathrm{~kg}^{-1}$ in the alkaline soil. The formation of root nodules consequently represented the most sensitive parameter to $\mathrm{Cu}$ in this work.

With respect to a sustainable soil use, the observed responses emphasize a careful and advised soil $\mathrm{Cu}$ management, especially in the more sensitive acidic, sandy soils, on which mitigation and remediation strategies should to focus. Assuming the current annual $\mathrm{Cu}$ application limits of $6 \mathrm{~kg} \mathrm{Cu} \mathrm{ha}^{-1}$ (EC 2008) and expecting plant withdrawals of $2-3 \mathrm{~kg} \mathrm{ha}^{-1}$ the mentioned toxicity thresholds would be reached after 38-51 years in the acidic soil and after 573-764 years in the alkaline soil.

Acknowledgements We thank family Pinter from Lasberg and family Fanzler from Deutsch Jahrndorf for providing soil. The fungicide was supplied from Spiess-Urania and the seeds as well as the rhizobiainoculum from Saatgut Freudenberger. We also thank Alexander Bruckner, Matthieu Platzer and Lieselotte Ziegler of the Institute of Zoology, University of Natural Resources and Life Sciences for their contribution to the experimental planning and implementation and Notburga Gierlinger and Barbara Stefke of the Institute of Biophysics, University of Natural Resources and Life Sciences for sectioning of root nodules. Open access funding provided by University of Natural Resources and Life Sciences Vienna (BOKU).

Funding This study was funded by the Federal Ministry of Agriculture, Forestry, Environment and Water Management with the project "Copper stabilization in vineyard soils" (BMLFUW, project number 100888).

\section{Compliance with ethical standards}

Conflict of interest The authors declare that they have no conflict of interest.

Ethical approval This article does not contain any studies with human participants or animals performed by any of the authors.

Publisher's note: Springer Nature remains neutral with regard to jurisdictional claims in published maps and institutional affiliations.

Open Access This article is distributed under the terms of the Creative Commons Attribution 4.0 International License (http://crea tivecommons.org/licenses/by/4.0/), which permits unrestricted use, distribution, and reproduction in any medium, provided you give appropriate credit to the original author(s) and the source, provide a link to the Creative Commons license, and indicate if changes were made.

\section{References}

Amelung W, Blume H-P, Fleige H, Horn R, Kandeler E, KögelKnabner I, Kretzschmar R, Stahr K, Wilke B-M (2018) Scheffer/ Schachtschabel Lehrbuch der Bodenkunde. Springer, Berlin Heidelberg

Arora NK, Khare E, Singh S, Maheshwari DK (2010) Effect of Al and heavy metals on enzymes of nitrogen metabolism of fast and slow growing rhizobia under explanta conditions. World J Microbiol Biotechnol 26:811-816

Ashrafi E, Zahedi M, Razmjoo J (2014) Co-inoculations of arbuscular mycorrhizal fungi and rhizobia under salinity in alfalfa. Soil Sci Plant Nutr 60:619-629

Baijukya F, Semu E (1998) Effects of Kocide $101^{\circledR}$ on the bean (Phaseolus vulgaris L.)-Rhizobium symbiosis. Acta Agric Scand B 48:175-183

BBodSchV, 1999. Federal soil protection and contaminated sites ordininance (BBodSchV) dated 12 July 1999., BGBL. I S. 3465, Bonn. Germany. 
Bellenger J, Xu Y, Zhang X, Morel F, Kraepiel A (2014) Possible contribution of alternative nitrogenases to nitrogen fixation by asymbiotic N 2-fixing bacteria in soils. Soil Biol Biochem 69:413-420

Berger E, Dersch G, Dellantonio A, Duboc O, Manner K, MöbesHansen B, Stemmer M (2012) Kupfer als Pflanzenschutzmittel - Strategie für einen nachhaltigen und umweltschonenden Einsatz. Austrian Agency for Health and Food safety, Vienna, Austria

Brandstätter C, Keiblinger K, Wanek W, Zechmeister-Boltenstern S (2013) A closeup study of early beech litter decomposition: potential drivers and microbial interactions on a changing substrate. Plant Soil 371:139-154

Bravin M, Tentscher P, Rose J, Hinsinger P (2009) Rhizosphere pH gradient controls copper availability in a strongly acidic soil. Environ Sci Technol 43:5686-5691

Bravin MN, Le Merrer B, Denaix L, Schneider A, Hinsinger P (2010) Copper uptake kinetics in hydroponically-grown durum wheat (Triticum turgidum durum L.) as compared with soil's ability to supply copper. Plant Soil 331:91-104

Brennicke A, Schopfer P (2010) Pflanzenphysiologie. Springer, Heidelberg

Broos K, Uyttebroek M, Mertens J, Smolders E (2004) A survey of symbiotic nitrogen fixation by white clover grown on metal contaminated soils. Soil Biol Biochem 36:633-640

Caetano AL, Marques CR, Gonçalves F, da Silva EF, Pereira R (2016) Copper toxicity in a natural reference soil: ecotoxicological data for the derivation of preliminary soil screening values. Ecotoxicology 25:163-177

Cestone B, Vogel-Mikuš K, Quartacci MF, Rascio N, Pongrac P, Pelicon P, Vavpetič P, Grlj N, Jeromel L, Kump P (2012) Use of micro-PIXE to determine spatial distributions of copper in Brassica carinata plants exposed to $\mathrm{CuSO} 4$ or CuEDDS. Science Total Environ 427:339-346

Chaudri A, McGrath S, Gibbs P, Chambers B, Carlton-Smith C, Bacon J, Campbell C, Aitken M (2008) Population size of indigenous Rhizobium leguminosarum biovar trifolii in long-term field experiments with sewage sludge cake, metal-amended liquid sludge or metal salts: effects of zinc, copper and cadmium. Soil Biol Biochem 40:1670-1680

Chen B-C, Ho P-C, Juang K-W (2013) Alleviation effects of magnesium on copper toxicity and accumulation in grapevine roots evaluated with biotic ligand models. Ecotoxicology $22: 174-183$

Cornu JY, Staunton S, Hinsinger P (2007) Copper concentration in plants and in the rhizosphere as influenced by the iron status of tomato (Lycopersicon esculentum L.). Plant Soil 292:63-77

Dahlin S, Witter E, Mårtensson A, Turner A, Bååth E (1997) Where's the limit? Changes in the microbiological properties of agricultural soils at low levels of metal contamination. Soil Biol Biochem 29:1405-1415

Degryse F, Shahbazi A, Verheyen L, Smolders E (2012) Diffusion limitations in root uptake of cadmium and zinc, but not nickel, and resulting bias in the Michaelis constant. Plant Physiol 160:1097-1109

Degryse F, Smolders E, Zhang H, Davison W (2009) Predicting availability of mineral elements to plants with the DGT technique: a review of experimental data and interpretation by modelling. Environ Chem 6:198-218

Díaz J, Bernal A, Pomar F, Merino F (2001) Induction of shikimate dehydrogenase and peroxidase in pepper (Capsicum annuum L.) seedlings in response to copper stress and its relation to lignification. Plant Science 161:179-188

EC (2008) Commission regulation (EC). In: Commission E. (ed.) No 889/2008. European Commission, Official Journal of the European Union, pp 1-84
Elbana TA, Selim HM (2011) Copper mobility in acidic and alkaline soils: Miscible displacement experiments. Soil Sci Soc Am J 75:2101-2110

Freundlich H (1909) Kapillarchemie, eine Darstellung der Chemie der Kolloide und verwandter Gebiete. Verlag der Akademischen Verlagsgesellschaft, Leipzig

Girotto E, Ceretta CA, Brunetto G, Miotto A, Tiecher TL, De Conti L, Lourenzi CR, Lorensini F, Gubiani PI, Da Silva LS (2014) Copper availability assessment of $\mathrm{Cu}$-contaminated vineyard soils using black oat cultivation and chemical extractants. Environ Monit Assess 186:9051-9063

González-Guerrero M, Escudero V, Saéz Á, Tejada-Jiménez M (2016) Transition metal transport in plants and associated endosymbionts: Arbuscular mycorrhizal fungi and rhizobia. Frontiers Plant Sci 7:1-21

Halliwell B, Gutteridge J (1984) Oxygen toxicity, oxygen radicals, transition metals and disease. Biochem J 219:1

Harper MP, Davison W, Zhang H, Tych W (1998) Kinetics of metal exchange between solids and solutions in sediments and soils interpreted from DGT measured fluxes. Geochim Cosmochim Acta 62:2757-2770

Hille R, Rétey J, Bartlewski-Hof U, Reichenbecher W, Schink B (1998) Mechanistic aspects of molybdenum-containing enzymes. FEMS Microbiol Rev 22:489-501

Houba V, Temminghoff E, Gaikhorst G, Van Vark W (2000) Soil analysis procedures using $0.01 \mathrm{M}$ calcium chloride as extraction reagent. Commun Soil Sci Plant Anal 31:1299-1396

Ippolito JA, Ducey TF, Tarkalson DD (2011) Interactive effects of copper on alfalfa growth, soil copper, and soil bacteria. J Agr Sci $3: 138$

Kabata-Pendias A (2004) Soil-plant transfer of trace elements-an environmental issue. Geoderma 122:143-149

Keiblinger KM, Schneider M, Gorfer M, Paumann M, Deltedesco E, Berger H, Jöchlinger L, Mentler A, Zechmeister-Boltenstern S, Soja G, Zehetner F (2018) Assessment of Cu applications in two contrasting soils-effects on soil microbial activity and the fungal community structure. Ecotoxicology 27:217-233

Kühne S, Strassemeyer J, Rossberg D (2009) Use of copper containing plant protection products in Germany. J Kulturpflanzen 61:126-130

Lair G, Gerzabek M, Haberhauer G (2007) Retention of copper, cadmium and zinc in soil and its textural fractions influenced by long-term field management. Eur J Soil Sci 58:1145-1154

Lair GJ, Gerzabek MH, Haberhauer G, Jakusch M, Kirchmann H (2006) Response of the sorption behavior of $\mathrm{Cu}, \mathrm{Cd}$, and $\mathrm{Zn}$ to different soil management. J Plant Nutr Soil Sci 169:60-68

Lindsay WL (1979) Chemical equilibria in soils. John Wiley and Sons Ltd., Chichester, Sussex

Michaud AM, Bravin M, Galleguillos M, Hinsinger P (2007) Copper uptake and phytotoxicity as assessed in situ for durum wheat (Triticum turgidum durum L.) cultivated in $\mathrm{Cu}$-contaminated, former vineyard soils. Plant Soil 298:99-111

Mostofa MG, Fujita M (2013) Salicylic acid alleviates copper toxicity in rice (Oryza sativa L.) seedlings by up-regulating antioxidative and glyoxalase systems. Ecotoxicology 22:959-973

Ninkov J, Vasin J, Milic S, Sekulic P, Zeremski T, Milenkovic S (2014) Copper content and distribution in vineyard soils of central Serbia. Eurasian J Soil Sci 3:131

OENorm-L1061-2 (2002) Chemical analysis of soils, Determination of particle size distribution in mineral soils-Part 2: Fine soil. Austrian Standards Institute, Vienna

OENorm-L1079 (1999) Chemical analysis of soils, Determination of soil organic matter by loss on ignition. Austrian Standards Institute, Vienna

OENorm-L1083 (2006) Chemical analysis of soils, Determination of the acidity. Austrian Standards Institute, Vienna 
OENorm-L1085 (2009) Chemical analysis of soils, Extraction of elements with aqua regia or with a mixture of nitric- and perchloric-acid. Austrian Standards Institute, Vienna

OENorm-L1087 (2004) Chemical analysis of soils, Determination of "plant-available" phosphorus and potassium using calcium acetate lactate (CAL) method. Austrian Standards Institute, Vienna

OENorm-L1089 (2005) Chemical analysis of soils, EDTA-extract for the determination of heavy metals. Austrian Standards Institute, Vienna

OENorm-L1095 (2002) Chemical analysis of soils, Determination of total nitrogen by dry combustion. Austrian Standards Institute, Vienna

Peralta-Videa J, Gardea-Torresdey J, Gomez E, Tiemann K, Parsons J, Carrillo G (2002) Effect of mixed cadmium, copper, nickel and zinc at different $\mathrm{pHs}$ upon alfalfa growth and heavy metal uptake. Environ Pollut 119:291-301

Pietrzak U, McPhail D (2004) Copper accumulation, distribution and fractionation in vineyard soils of Victoria, Australia. Geoderma 122:151-166

Porter JR, Sheridan RP (1981) Inhibition of nitrogen fixation in alfalfa by arsenate, heavy metals, fluoride, and simulated acid rain. Plant Physiol 68:143-148

Preisig O, Zufferey R, Thöny-Meyer L, Appleby CA, Hennecke H (1996) A high-affinity cbb3-type cytochrome oxidase terminates the symbiosis-specific respiratory chain of Bradyrhizobium japonicum. J Bacteriol 178:1532-1538

Quilliam RS, DeLuca TH, Jones DL (2013) Biochar application reduces nodulation but increases nitrogenase activity in clover. Plant Soil 366:83-92

R-Development-Core-Team (2015) R: A language and environment for statistical computing. R Foundation for Statistical Computing, Vienna, Austria

Rodríguez-Haas B, Finney L, Vogt S, González-Melendi P, Imperial J, González-Guerrero M (2013) Iron distribution through the developmental stages of Medicago truncatula nodules. Metallomics 5:1247-1253

Schinner F, Öhlinger R, Kandeler E, Margesin R (1996). Methods in soil biology, 1 ed. Springer-Verlag, Berlin Heidelberg

Snowball K, Robson A, Loneragan J (1980) The effect of copper on nitrogen fixation in subterranean clover (Trifolium subterraneum). New Phytol 85:63-72

Tao S, Liu W, Chen Y, Xu F, Dawson R, Li B, Cao J, Wang X, Hu J, Fang J (2004) Evaluation of factors influencing root-induced changes of Copper fractionation in rhizosphere of a calcareous soil. Environ Pollut 129:5-12

Voigt A, Hendershot WH, Sunahara GI (2006) Rhizotoxicity of Cadmium and Copper in soil extracts. Environ Toxicol Chem 25:692-701

Wenzel WW, Oburger E, Puschenreiter M, Santner J (2011) Trace element biogeochemistry in the rhizosphere. Dynamics and bioavailability of heavy metals in the rootzone. CRC Press/Taylor \& Francis, Boca Raton/London/New York, pp 147-181

White PJ (2012). Heavy metal toxicity in plants. In: Shabala $S$ (ed.) Plant stress physiology. CAB International, Oxfordshire, pp 210-237, https://doi.org/10.1079/9781845939953.0210

Wu Y, Hendershot WH (2010) Effect of Calcium and pH on Copper binding and rhizotoxicity to pea (Pisum sativum L.) root: empirical relationships and modeling. Archf Environ Contam Toxicol 59:109-119

Zechmeister-Boltenstern SSF (1993) Bestimmung der Nitrogenaseaktivität mittels Acetylenreduktion. In: Schinner F, Öhlinger R, Kandeler E, Margesin R (eds) Bodenbiologische Arbeitsmethoden Springer, Berlin Heidelberg, pp 141-146

Zhang H (2005) Practical guide for making diffusive gel and chelex gel. DGT Research Ltd., Lancaster

Zorn W, Marks G, Heß H, Bergmann W (2013) Handbuch zur visuellen Diagnose von Ernährungsstörungen bei Kulturpflanzen. Springer, Berlin Heidelberg 